\title{
Screening of African Yam Bean Accessions for Imbibition and Seed Physiological Quality
}

\author{
Catherine Veronica Nnamani ${ }^{1}$, Femi Emmanuel Awosanmi ${ }^{2} \&$ Sunday Adesola Ajayi ${ }^{2,3}$ \\ ${ }^{1}$ Plant Systematics and Conservation Biology Research Lab, Department of Applied Biology, Ebonyi State \\ University, Abakaliki, Nigeria \\ ${ }^{2}$ Department of Crop Production and Protection, Obafemi Awolowo University, Ile-Ife, Nigeria \\ ${ }^{3}$ Institute for Sustainable Development, First Technical University, Ibadan, Nigeria \\ Correspondence: Femi E. Awosanmi, Department of Crop Production and Protection, Obafemi Awolowo \\ University, Ile-Ife 220282, Nigeria. Tel: 234-803-085-1956. E-mail: femiawosanmi@oauife.edu.ng
}

Received: January 17, 2021

Accepted: March 1, $2021 \quad$ Online Published: April 15, 2021

doi:10.5539/jas.v13n5p81

URL: https://doi.org/10.5539/jas.v13n5p81

\begin{abstract}
African yam bean is a nutritionally-important but neglected food crop with several health benefits. But its large scale cultivation and consumption are still limited by lack of systematic genetic improvement and breeding programme for the crop. Preliminary studies have established that the inherent field establishment potential of African yam bean is low. Hence the need to screen available accessions to identify those with outstanding seed physiological qualities for selection as parental materials for further improvement. Thirty-four African yam bean accessions were collected from different farmers in five states of Southeastern Nigeria. Seed physiological quality (viability and vigour) was assessed using hundred seed weight, water imbibition, standard germination, accelerated ageing and conductivity tests. The mean squares due to varietal effect were significant $(p<0.05)$ for germination index and highly significant $(\mathrm{p}<0.01)$ for all other traits. Accessions ENAGag, ENAGmg 1 and; ENAGmg 2 had high standard $(>80 \%)$ and accelerated ageing $(>70 \%)$ germination percentages. Only 11 of the accessions had an accelerated ageing germination percentage of above $50 \%$. All but one of the 34 accessions had conductivity values less than $5.00 \mu \mathrm{Scm}^{-1} \mathrm{~g}^{-1}$. On the average, African yam bean seeds require up to $76.9 \%$ moisture of their initial weight over a period of approximately 53 hours prior for the commencement of germination process. Accessions ENAGag, ENAGmg 1, ENAGmg 2, ENNKob, ENNSog, IMISis, IMOKeo 1 and IMOKeo 3 were outstanding and are therefore potential candidates for genetic improvement of seed quality in African yam bean.
\end{abstract}

Keywords: accelerated aging, African yam bean, conductivity, germination, imbibition

\section{Introduction}

African yam bean [Sphenostylis stenocarpa (ex. A. Rich.) Harms] is an underutilized indigenous legume consumed for its nutritious grains and tubers (Potter \& Doyle, 1992). It is cultivated throughout West Africa countries particularly, Cameroon, Cote d'Ivore, Ghana, Nigeria and Togo (Potter, 1992). It is a perennial climbing species whose morphotypes may be prostrate or erect and about 1-3 $\mathrm{m}$ in height. Its leaves are trifoliate, 2.7 to $13 \mathrm{~cm}$ long and 0.2 to $5.5 \mathrm{~cm}$ broad (Nnamani et al., 2017). The edible seeds have high amino acid content (lysine and methionine) which has been reported to be higher than those of pigeon pea, cowpea, and Bambara groundnut (Uguru \& Madukaife, 2001). It is commonly cultivated by traditional farmers along the South West and South East regions of Nigeria (Nnamani et al., 2017). The propagation of African yam bean (AYB) is predominantly through seeds and despite its great nutritional potentials, the consumption and cultivation of the legume is still limited by lack of systematic genetic improvement studies on the crop. While $55 \%$ of farmers cultivating AYB in South East Nigeria reported poor availability of seeds, $60 \%$ reported poor seed quality as constraints to the extensive cultivation of African yam bean (Nnamani et al., 2017).

Seed viability and vigour constitute the physiological component of seed quality. Seed viability is the ability of the seed to germinate under optimal conditions, while seed vigor denotes inherent ability of seeds to emerge uniformly even under adverse environmental conditions in the field (Kandasamy et al., 2020). Low-vigor seeds emerge less uniformly than high-vigor seeds (Egli \& Rucker, 2012), and delay in emergence affects the 
subsequent stages of growth such as the seedling's competitive ability for light, water, and nutrients. These irregularities in crop emergence and development within a population result in decreased yield (Finch-Savage, 1995). Higher plant biomass and yield have been attributed to seeds with high physiological potential (Höfs, Schoeman, \& Vaissayrel, 2004; Egli \& Rucker, 2012). The extent that reserved food in seeds supports seedling establishment is not fully understood, nor is the variation in different varieties and the sizes of their seeds within the same variety/hybrids, since the small and large seeds tend to have different amounts and compositions of nutritional reserves (Eggert \& von Wirén, 2015). Venuto, Redfearn, Pitman, \& Alison, (2002) showed that seed weight significantly influences germination, seedling vigor and seasonal yield performance of annual ryegrass cultivars.

Vigour tests are efficient in identifying less advanced stages of seed deterioration and they facilitate decision making in seed production enterprises, especially in establishing storage, commercialization, and quality control policies (Medeiros, Silva, Capobiango, Fialho, \& Dias, 2019). The main objective of vigor tests is to identify possible differences in the physiological potential of seed lots which have similar germination percentages (Marcos-Filho, 2015). The use of tests based on different principles could be combined to present more reliable response with respect to the physiological potentials of the seed lots. Among vigor tests, accelerated ageing and electrical conductivity tests are considered the most sensitive tests for categorizing seed lots (Medeiros et al., 2019). The accelerated ageing test provides valuable information regarding storage and field emergence potentials of seedlings (Marcos-Filho, 2015), while the electrical conductivity test is useful for speedy assessment of the integrity of cellular membranes in seeds (Silva, Lopes, Marcos-Filho, \& Vieira, 2012). It is known that degeneration of cell membranes is the first event in the seed deterioration process. The greater the conductivity value, the lower the seed germination and vigor, due to loss of cell membrane integrity (Medeiros et al., 2019). Therefore, the tests results reflect the physiological potential of seeds, and inferences can be made regarding the storage potential of diverse seed lots (Binotti et al., 2008).

The vigour of AYB seeds is known to be inherently low (Olisa, Ajayi, \& Akande, 2010a). But this inference was based on a limited number of accessions. Hence this study with the aim to screen 34 available accessions of African yam bean for viability cum vigour characteristics with the view of identifying accessions with outstanding seed physiological qualities for selection in breeding as well as conservation programmes.

\section{Materials and Methods}

\subsection{Seed Collection}

Thirty four African yam bean accessions were collected from different AYB stakeholders (farmers' gene bank and vendors) in five states of Southeastern Nigeria (Table 1). The study area was Southeastern Nigeria, comprising of Abia, Anambra, Ebonyi, Enugu and Imo States (Figure 1).

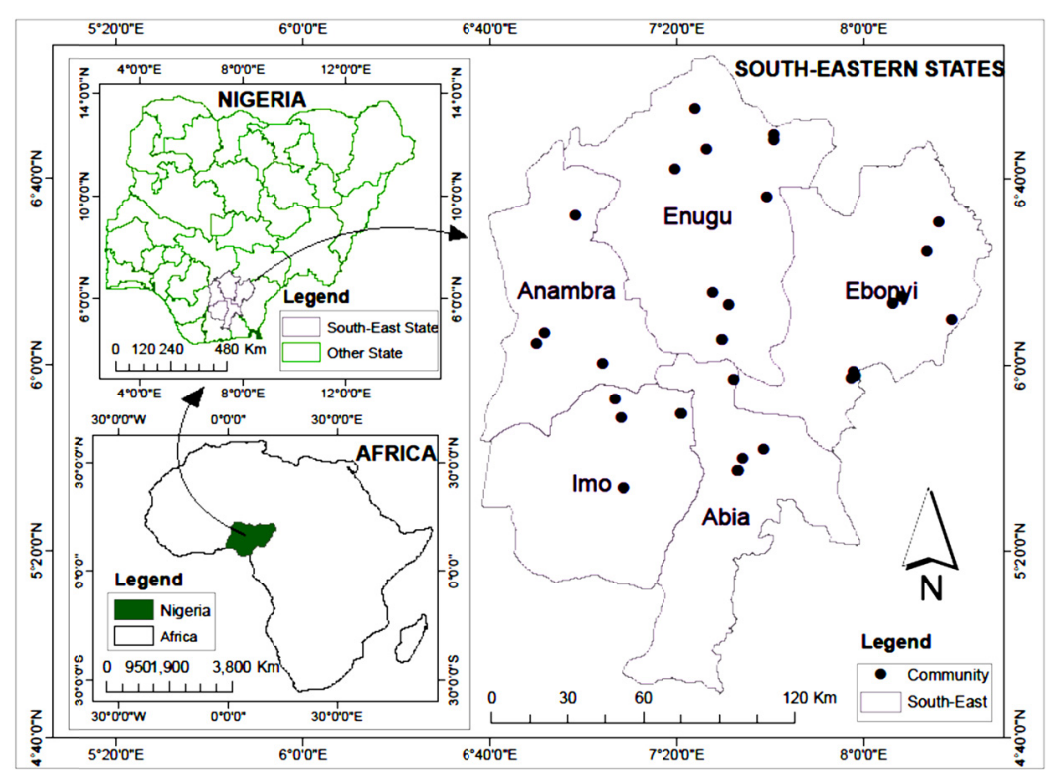

Figure 1. Southeastern states of Nigeria where samples of African yam bean (Sphenostylis stenocarpa) accessions were collected. Source (Nnamani et al., 2017) 
Table 1. Details of the Africa yam bean accessions collected within the Southeastern part of Nigeria

\begin{tabular}{|c|c|c|c|c|c|c|c|}
\hline $\mathrm{S} / \mathrm{N}$ & Sample Code & State & Commun & & Longitude & Latitude & Source \\
\hline 1 & ABBEuz & ABIA & Bende & Ngwu Uzoakoli & $7^{\circ} 55.07^{\prime} \mathrm{E}$ & $5^{\circ} 62.02^{\prime} \mathrm{N}$ & Farmer \\
\hline 2 & ABBEuz 1 & ABIA & Bende & Ngwu Uzoakoli & $7^{\circ} 55.23^{\prime} \mathrm{E}$ & $5^{\circ} 62.22^{\prime} \mathrm{N}$ & Farmer \\
\hline 3 & ABUNum 2 & ABIA & Umuahia North & Ubani Makt & $7^{\circ} 56.78^{\prime} \mathrm{E}$ & $5^{\circ} 66.23^{\prime} \mathrm{N}$ & Vendor \\
\hline 4 & ABBEng & ABIA & Bende & Ngwu & $7^{\circ} 55.08^{\prime} \mathrm{E}$ & $5^{\circ} 62.02^{\prime} \mathrm{N}$ & Farmer \\
\hline 5 & ABBEnu 1 & ABIA & Bende & Court & $7^{\circ} 64.26^{\prime} \mathrm{E}$ & $5^{\circ} 69.57^{\prime} \mathrm{N}$ & Farmer \\
\hline 6 & ANAGan & ANAMBRA & Aghamelum & Anaku & - & - & Vendor \\
\hline 7 & ANAGug & ANAMBRA & Aguata & Uga & - & - & Farmer \\
\hline 8 & ANINum & ANAMBRA & Idemili North & Umuoji & - & - & Farmer \\
\hline 9 & ANISnn & ANAMBRA & Idemili South & Nnobi & - & - & Market \\
\hline 10 & EBANam & EBONYI & Afipko North & Amata & $7^{\circ} 97.1^{\prime} \mathrm{E}$ & $5^{\circ} 96.57^{\prime} \mathrm{N}$ & Farmer \\
\hline 11 & EBANao 1 & EBONYI & Afipko North & Apku Oha & $7^{\circ} 96.34^{\prime} \mathrm{E}$ & $5^{\circ} 97.97 ’ \mathrm{~N}$ & Farmer \\
\hline 12 & EBANau & EBONYI & Afipko North & Apku Ugo & $7^{\circ} 95.47^{\prime} \mathrm{E}$ & $5^{\circ} 95.47^{\prime} \mathrm{N}$ & Farmer \\
\hline 13 & EBIKea & EBONYI & Ikwo & Eleke Achara & $8^{\circ} 13.56^{\prime} \mathrm{E}$ & $6^{\circ} 24.33^{\prime} \mathrm{N}$ & Farmer \\
\hline 14 & EBIKok & EBONYI & Ikwo & Okputomo & $8^{\circ} 10.43^{\prime} \mathrm{E}$ & $6^{\circ} 22.13^{\prime} \mathrm{N}$ & Farmer \\
\hline 15 & EBISlo & EBONYI & Ishielu & Labassa Okpoto & $7^{\circ} 51.82^{\prime} \mathrm{E}$ & $6^{\circ} 21.69^{\prime} \mathrm{N}$ & Farmer \\
\hline 16 & EBIZib & EBONYI & Izzi & Iboko & $8^{\circ} 22.59^{\prime} \mathrm{E}$ & $6^{\circ} 40.68^{\prime} \mathrm{N}$ & Farmer \\
\hline 17 & EBIZig & EBONYI & Izzi & Igboagu & - & - & Farmer \\
\hline 18 & EBIZwa & EBONYI & Izzi & Waka & $8^{\circ} 31.5^{\prime} \mathrm{E}$ & $6^{\circ} 16.44^{\prime} \mathrm{N}$ & Farmer \\
\hline 19 & ENAGag & ENUGU & Agwu & Agbaogugu & $7^{\circ} 46.07^{\prime} \mathrm{E}$ & $6^{\circ} 25.72^{\prime} \mathrm{N}$ & Farmer \\
\hline 20 & ENAGmg 1 & ENUGU & Agwu & Mgbowo & $7^{\circ} 49.57^{\prime} \mathrm{E}$ & $6^{\circ} 09.46^{\prime} \mathrm{N}$ & Farmer \\
\hline 21 & ENAGmg 2 & ENUGU & Agwu & Mgbowo & $7^{\circ} 49.57^{\prime} \mathrm{E}$ & $6^{\circ} 09.46^{\prime} \mathrm{N}$ & Farmer \\
\hline 22 & ENANam 2 & ENUGU & Aninri & Amoro & $7^{\circ} 53.7^{\prime} \mathrm{E}$ & $5^{\circ} 95.1^{\prime} \mathrm{N}$ & Farmer \\
\hline 23 & ENISib & ENUGU & Igboeze South & Ibagwa & $7^{\circ} 39.84^{\prime} \mathrm{E}$ & $6^{\circ} 91.63^{\prime} \mathrm{N}$ & Farmer \\
\hline 24 & ENIWea & ENUGU & Igbetiti West & Eke Aku & $7^{\circ} 32.68^{\prime} \mathrm{E}$ & $6^{\circ} 70.29^{\prime} \mathrm{N}$ & Farmer \\
\hline 25 & ENNEub & ENUGU & Nkanu East & Ubahu & $7^{\circ} 67.93^{\prime} \mathrm{E}$ & $6^{\circ} 80.52^{\prime} \mathrm{N}$ & Vendor \\
\hline 26 & ENNKob & ENUGU & Nkanu East & Obe & $7^{\circ} 67.94^{\prime} \mathrm{E}$ & $6^{\circ} 82.56^{\prime} \mathrm{N}$ & Farmer \\
\hline 27 & ENNSeh & ENUGU & Nsukka & Ehandagu & $7^{\circ} 65.24^{\prime} \mathrm{E}$ & $6^{\circ} 59.90^{\prime} \mathrm{N}$ & Farmer \\
\hline 28 & ENNSog & ENUGU & Nsukka & Ogbaozara & $7^{\circ} 43.96^{\prime} \mathrm{E}$ & $6^{\circ} 77.26^{\prime} \mathrm{N}$ & Farmer \\
\hline 29 & IMIKum & IMO & Ikeduru & Umudi & - & - & Vendor \\
\hline 30 & IMINak & IMO & Ideato North & Akuokwa & - & Farmer & Farmer \\
\hline 31 & IMISis & IMO & Ideato South & Isiekenesi & - & - & Vendor \\
\hline 32 & IMOKeo 1 & IMO & Okigwe & Eke Okigwe & $7^{\circ} 34.95^{\prime} \mathrm{E}$ & $5^{\circ} 82.56^{\prime} \mathrm{N}$ & Farmer \\
\hline 33 & IMOKeo 2 & IMO & Okigwe & Eke Okigwe & $7^{\circ} 34.96^{\prime} \mathrm{E}$ & $5^{\circ} 82.57^{\prime} \mathrm{N}$ & Farmer \\
\hline 34 & IMOKeo 3 & IMO & Okigwe & Eke Okigwe & $7^{\circ} 34.96^{\prime} \mathrm{E}$ & $5^{\circ} 82.57^{\prime} \mathrm{N}$ & Farmer \\
\hline
\end{tabular}

Source: Field survey, 2016.

\subsection{Hundred Seed Weight}

One hundred seeds in three (3) replicates of each accession were counted and weighed using a sensitive measuring scale.

\subsection{Standard Germination Test}

This test was conducted following International Seed Testing Association (ISTA) 2018 rules (ISTA, 2018). Fifty seeds in four replicates were planted on moistened sterilized riverbed sand for 10 days in plastic bowls and covered with transparent polythene sheets to maintain humidity. Counts were taken daily from the 3rd to the 10th day after planting (DAP) (Olisa et al., 2010a). Germination was assessed as a percentage of seeds producing normal seedlings as defined by ISTA (International Seed Testing Association) rules:

$$
\text { Germination percentage }(\mathrm{GPCT})=\frac{100 \times \text { Number of seedlings emerged 10DAP }}{\text { Total number of seeds planted }}
$$

Germination index (GI): This was calculated as proposed by Fakorede and Agbana (1983) as,

$$
\text { Germination Index }=\frac{\sum[(\text { number of plants emerged in a day })(\mathrm{DAP})]}{\text { Total Number of plants emerged by the } 10^{\text {th }} \text { day }}
$$




\subsection{Accelerated Ageing Test}

Fifty seeds in three replicates from each of the accessions were weighed and placed in wire mesh in accelerated ageing boxes containing $40 \mathrm{ml}$ of distilled water. The seeds were aged by placing them in an accelerated ageing chamber at $43^{\circ} \mathrm{C}$ for $72 \mathrm{~h}$ at the end of which the seeds were re-weighed. The amount of water imbibed during the ageing (WIA) process was calculated as the difference between the final and initial weights (g) of the seeds and expressed as a percentage of initial weight. Standard germination test was then conducted with the aged seeds as described above to achieve the accelerated ageing germination percentage (AAT). Accelerated ageing germination index (AAI) was calculated by substituting the germination counts after accelerated ageing into the formula used earlier to obtain germination index.

\subsection{Conductivity Test}

Three replicates of 50 pre-weighed seeds from each accession were soaked for $24 \mathrm{~h}$ in $100 \mathrm{ml}$ distilled water in $200 \mathrm{ml}$ conical flasks covered with aluminium foils to prevent contamination. The conductivity of water was also measured using a flask with $100 \mathrm{ml}$ distilled water without seeds. Conductivity was measured using Jenway 4510 (Bibby Scientific Ltd., Staffordshire, UK) conductivity meter. The results were expressed as $\mu \mathrm{Scm}^{-1} \mathrm{~g}^{-1}$ :

$$
\text { Conductivity }(\mathrm{COND})=\frac{\text { Conductivity }(\mu \mathrm{S}) \text { for each flask }- \text { Conductivity of distilled water }}{\text { Initial weight }(\mathrm{g}) \text { of seed sample }}
$$

\subsection{Vigour Index}

Vigour index was calculated as an average of the percentage difference across the treatments in each of the tests (Awosanmi, 2010). The higher the VI, the more stable the genotype.

$$
\mathrm{VI}=[(\mathrm{GPCT}+\mathrm{AAT}+\mathrm{COND} \%) / 3]
$$

Where, GPCT $=$ Germination percentage, $\mathrm{AAT}=$ Accelerated ageing germination percentage, $\mathrm{COND}=$ conductivity.

Conductivity values were converted to $\%$ as follows:

$$
\mathrm{COND} \%=[100 \times(30-\mathrm{COND}) / 30]
$$

Given that lower conductivity values indicate higher quality, the factor 30 was used based on interpretation of conductivity values in relation to field emergence as suggested by Hampton and TeKrony (1995). Therefore, seed lots with conductivity values greater than $30 \mu \mathrm{Scm}^{-1} \mathrm{~g}^{-1}$ were regarded as not suitable for sowing especially under adverse weather conditions (Awosanmi, 2010).

\subsection{Water Imbibition Test}

This was carried out by planting 10 pre-weighed individual seeds from each accession in pre-numbered positions on a paper towel in a covered transparent plastic box. This was replicated 3 times. The seeds were removed at intervals of $6 \mathrm{~h}$, weighed and returned to continue imbibition until sprouting or the emergence of the radicle. The duration of imbibition (DIM) was the period in hours from the planting to the time $50 \%$ of the seeds per replicate emerged radicle. The amount of water imbibed was then calculated and expressed in percentage (WIP) as the difference between the initial and final weights according to Olisa, Ajayi, and Akande (2010b).

\subsection{Statistical Analyses}

Analysis of variance was carried out using statistical analysis system (SAS) and the means were separated using least significant difference (LSD) at 1 and 5\% levels of probability. Correlation analysis was also carried out to evaluate the relationship among the tests.

\section{Results}

There were significant accession effects for all the traits: hundred seed weight, germination percentage, germination index, water imbibed during ageing, accelerated ageing germination percentage, accelerated ageing germination index, conductivity, vigour index, water imbibition percentage and duration of imbibition (Table 2). The coefficient of variation was less than 20 for 7 out of the 10 traits assessed, the exceptions being germination percentage, accelerated ageing water imbibed and accelerated ageing test. Also, the coefficients of determination $\left(\mathrm{R}^{2}\right)$ values were high $(>70 \%)$ for hundred seed weight, germination percentage, accelerated ageing germination percentage, conductivity, vigour index, water imbibition percentage and duration of imbibition, and moderate (50-69\%) for germination index, water imbibed during ageing and accelerated ageing germination index (Table 2). 
Table 2. Mean square values from the Analysis of variance of the 34 African yam bean accessions subjected to seed physiological tests.

\begin{tabular}{llllllllllll}
\hline SV & df & HSW & GPCT & GI & WIA & AAT & AAI & COND & VI & WIP & DIMB \\
\hline Rep & 2 & 0.36 & 538.16 & 0.58 & 50.44 & 265.53 & 0.18 & 0.13 & $169.17^{* *}$ & 18.32 & 1.06 \\
Acc & 33 & $143.69^{* *}$ & $2315.17^{* *}$ & $0.81^{*}$ & $112.86^{* *}$ & $1878.15^{* *}$ & $0.71^{* *}$ & $2.84^{* *}$ & $813.95^{* *}$ & $67.24^{* *}$ & $158.56^{* *}$ \\
Error & 66 & 2.54 & 173.23 & 0.41 & 27.38 & 106.50 & 0.24 & 0.13 & 28.66 & 10.62 & 0.70 \\
\hdashline Mean & 33.29 & 64.31 & 5.07 & 22.80 & 34.82 & 4.93 & 3.18 & 62.85 & 76.90 & 52.76 \\
CV & & 4.79 & 20.46 & 12.64 & 22.95 & 29.63 & 9.89 & 11.39 & 8.52 & 4.24 & 1.58 \\
$\mathrm{R}^{2}$ & & $96.58^{* *}$ & $87.14 * *$ & $51.09^{*}$ & $67.91^{* *}$ & $89.89^{* *}$ & $60.73 * *$ & $91.59 * *$ & $93.50^{* *}$ & $76.30^{* *}$ & $99.13^{* *}$ \\
\hline
\end{tabular}

Note. SV: Sources of variation; df: degrees of freedom; Rep: Replication; Acc: Accession; HSW: Hundred Seed weight (g); GPCT: Germination percentage (\%); GI: Germination index; WIA: Water imbibed during accelerated ageing (\%); AAT: Accelerated ageing germination percentage (\%); AAI: Accelerated ageing germination index; COND: Conductivity per gram of seed $\left(\mu \mathrm{Scm}^{-1} \mathrm{~g}^{-1}\right)$; VI: Vigour index; WIP: Percentage water imbibed (\%); DIM: Duration of imbibition (hrs).

Significant differences existed in the seed physiological quality of the AYB seeds collected from the 5 states in Southeast, Nigeria. Seeds collected from Enugu State had outstanding seed physiological traits in terms of hundred seed weight, highest germination percentage, accelerated ageing germination percentage and highest vigour index. While seeds from Anambra State performed poorly among the other states (Table 3).

Table 3. Mean values of the performance of the 34 African yam bean accessions for seed physiological tests across the states of collection

\begin{tabular}{lllllllllll}
\hline States & HSW & GPCT & GI & WIA & AAT & AAI & COND & VI & WIP & DIM \\
\hline Abia & 35.62 & 68.53 & 5.42 & 19.68 & 31.20 & 5.36 & 2.65 & 63.63 & 74.48 & 60.80 \\
Anambra & 30.64 & 43.00 & 5.65 & 19.70 & 21.33 & 5.50 & 4.27 & 50.04 & 75.98 & 56.00 \\
Ebonyi & 29.79 & 57.85 & 4.91 & 24.85 & 20.96 & 4.75 & 3.36 & 55.88 & 79.47 & 47.33 \\
Enugu & 37.50 & 72.47 & 4.95 & 21.80 & 49.47 & 4.77 & 3.03 & 70.62 & 75.65 & 52.80 \\
Imo & 31.37 & 71.11 & 4.93 & 26.01 & 43.22 & 4.78 & 2.88 & 68.25 & 77.76 & 52.00 \\
\hdashline LSD $_{0.05}$ & 2.60 & 21.46 & 1.04 & 8.53 & 16.82 & 0.80 & 0.59 & 8.73 & 5.31 & 1.36 \\
\hline
\end{tabular}

Note. HSW: Hundred Seed weight (g); GPCT: Germination percentage (\%); GI: Germination index; WIA: Water imbibed during accelerated aging (\%); AAT: Accelerated ageing germination percentage (\%); AAI: Accelerated aging germination index; COND: Conductivity per gram of seed $\left(\mu \mathrm{Scm}^{-1} \mathrm{~g}^{-1}\right)$; VI: Vigour index; WIP: Percentage water imbibed (\%); DIM: Duration of imbibition (hrs).

The accessions differed widely in HSW, ranging from 22.70 to $52.83 \mathrm{~g}$. Out of the 34 accessions evaluated, 11 had HSW $<30 \mathrm{~g}, 13$ were 30-35 g, 7 were 36-40 g, and 3 had HSW $>40 \mathrm{~g}$ (Table 4). 33 of the 34 accessions had germination percentages ranging from 2.67 to $98 \%$. Only 9 accessions had germination percentage that was less than $50 \%$ while for more than half of the accessions, germination percentage was above $70 \%$. Unlike seed weight (HSW) and viability (GPCT), germination index, GI, was less variable, ranging from 3.98-6.61 days with a mean of 5.07 days. The range of the amount of water imbibed varied widely. While ENIWea absorbed $130 \%$ and EBIZig and EBIZib up to $100 \%$ of the initial weight, ENAGmg series absorbed less than $50 \%$ of their respective weights (Table 4). Accessions ENAGag, ENAGmg 1, ENAGmg 2 also had germination percentages greater than $80 \%$ combined with germination percentage after accelerated ageing test (AAT) of above $70 \%$. Although ABBEuz, EBIKea, EBIZib, EBIZwa, ENNEub and IMOKeo 2 accessions had very high mean values for germination percentage $(>80 \%)$, the percentage of germination after being subjected to accelerated ageing test drastically reduced to beyond half of the initial germination percentage. 
Table 4. Mean values of the performance of the 34 African yam bean accessions when subjected to seed physiological tests

\begin{tabular}{|c|c|c|c|c|c|c|c|c|c|c|c|}
\hline States & Accession & HSW & GPCT & GI & WIA & AAT & AAI & COND & VI & WIP & DIM \\
\hline Abia & ABBE uz & 34.97 & 85.33 & 5.60 & 21.02 & 25.33 & 5.01 & 3.22 & 66.64 & 76.77 & 66.00 \\
\hline Abia & ABBEng & 38.89 & 76.67 & 5.12 & 20.23 & 56.67 & 5.49 & 2.45 & 75.05 & 73.53 & 58.00 \\
\hline Abia & ABBEnu 1 & 35.01 & 58.00 & 4.98 & 22.35 & 19.33 & 6.17 & 2.47 & 56.37 & 72.27 & 66.00 \\
\hline Abia & ABBEuz 1 & 36.76 & 64.67 & 5.32 & 19.30 & 36.00 & 5.63 & 1.87 & 64.81 & 73.02 & 60.00 \\
\hline Abia & ABUNum 2 & 32.47 & 58.00 & 6.08 & 15.50 & 18.67 & 4.50 & 3.24 & 55.29 & 76.83 & 54.00 \\
\hline Anambra & ANAGan & 31.38 & 26.00 & 6.61 & 21.91 & 30.00 & 4.97 & 3.21 & 48.43 & 77.71 & 54.00 \\
\hline Anambra & ANAGug & 33.68 & 84.00 & 5.02 & 19.90 & 22.00 & 5.43 & 3.20 & 65.11 & 75.70 & 50.00 \\
\hline Anambra & ANINum & 27.56 & 62.00 & 5.30 & 22.46 & 33.33 & 6.09 & 3.26 & 61.49 & 77.82 & 54.00 \\
\hline Anambra & ANISnn & 29.92 & 0.00 & - & 14.54 & 0.00 & - & 7.39 & 25.12 & 72.71 & 66.00 \\
\hline Ebonyi & EBANam & 32.81 & 49.33 & 4.84 & 25.26 & 7.33 & 4.79 & 4.72 & 46.98 & 81.49 & 42.00 \\
\hline Ebonyi & EBANao 1 & 32.91 & 66.00 & 4.86 & 25.80 & 10.67 & 5.27 & 3.32 & 55.20 & 77.96 & 54.00 \\
\hline Ebonyi & EBANau & 30.33 & 2.67 & 5.25 & 27.95 & 1.33 & 5.00 & 4.64 & 29.51 & 80.25 & 48.00 \\
\hline Ebonyi & EBIKea & 25.20 & 90.67 & 4.81 & 35.75 & 35.33 & 4.92 & 2.65 & 72.39 & 88.98 & 48.00 \\
\hline Ebonyi & EBIKok & 36.81 & 20.67 & 6.23 & 21.66 & 0.00 & - & 3.49 & 36.34 & 75.62 & 54.00 \\
\hline Ebonyi & EBISlo & 29.85 & 34.00 & 3.98 & 21.73 & 29.33 & 4.70 & 2.47 & 51.71 & 78.27 & 42.00 \\
\hline Ebonyi & EBIZib & 26.60 & 90.67 & 4.50 & 26.60 & 34.67 & 5.04 & 3.42 & 71.31 & 78.73 & 48.00 \\
\hline Ebonyi & EBIZig & 24.47 & 80.00 & 5.04 & 24.60 & 51.33 & 4.45 & 2.55 & 74.27 & 73.98 & 42.00 \\
\hline Ebonyi & EBIZwa & 29.13 & 86.67 & 4.74 & 14.33 & 18.67 & 3.88 & 2.93 & 65.19 & 79.97 & 48.00 \\
\hline Enugu & ENAGag & 50.87 & 97.33 & 4.82 & 21.97 & 70.00 & 4.30 & 3.81 & 84.88 & 64.10 & 54.00 \\
\hline Enugu & ENAGmg 1 & 52.83 & 86.00 & 4.81 & 17.33 & 91.33 & 4.81 & 3.17 & 88.92 & 66.53 & 60.00 \\
\hline Enugu & ENAGmg 2 & 48.88 & 93.33 & 4.77 & 18.56 & 74.67 & 4.98 & 3.62 & 85.31 & 70.51 & 60.00 \\
\hline Enugu & ENANam 2 & 31.35 & 98.00 & 5.02 & 15.03 & 50.67 & 5.02 & 2.73 & 79.86 & 81.49 & 42.00 \\
\hline Enugu & ENISib & 25.60 & 26.67 & 5.13 & 27.82 & 15.33 & 4.61 & 2.95 & 44.06 & 82.55 & 48.00 \\
\hline Enugu & ENIWea & 29.33 & 56.00 & 5.10 & 37.92 & 29.33 & 4.22 & 2.91 & 58.55 & 74.95 & 54.00 \\
\hline Enugu & ENNEub & 32.20 & 80.67 & 4.87 & 20.66 & 4.67 & 5.00 & 2.85 & 58.62 & 80.32 & 54.00 \\
\hline Enugu & ENNKob & 36.60 & 89.33 & 5.36 & 20.25 & 72.00 & 5.12 & 2.17 & 84.70 & 74.21 & 66.00 \\
\hline Enugu & ENNSeh & 32.86 & 33.33 & 4.79 & 20.01 & 21.33 & 4.90 & 3.54 & 47.63 & 79.62 & 42.00 \\
\hline Enugu & ENNSog & 34.53 & 64.00 & 4.79 & 18.49 & 65.33 & 4.71 & 2.51 & 73.66 & 82.20 & 48.00 \\
\hline Imo & IMIKum & 34.28 & 32.67 & 4.42 & 29.91 & 18.00 & 4.56 & 3.95 & 45.83 & 78.64 & 48.00 \\
\hline Imo & IMINak & 36.55 & 60.67 & 4.47 & 18.75 & 11.33 & 4.39 & 2.74 & 54.29 & 79.91 & 48.00 \\
\hline Imo & IMISis & 24.28 & 96.67 & 5.24 & 34.29 & 70.67 & 5.03 & 2.52 & 86.31 & 81.76 & 54.00 \\
\hline Imo & IMOKeo 1 & 22.70 & 73.33 & 4.88 & 35.37 & 68.00 & 4.62 & 3.06 & 77.05 & 74.54 & 48.00 \\
\hline Imo & IMOKeo 2 & 33.47 & 91.33 & 4.96 & 18.16 & 31.33 & 5.09 & 2.61 & 71.33 & 75.36 & 54.00 \\
\hline \multirow[t]{2}{*}{ Imo } & IMOKeo 3 & 36.91 & 72.00 & 5.59 & 19.89 & 60.00 & 4.97 & 2.38 & 74.69 & 76.38 & 60.00 \\
\hline & $\mathrm{LSD}_{0.05}$ & 2.60 & 21.46 & 1.04 & 8.53 & 16.82 & 0.80 & 0.59 & 8.73 & 5.31 & 1.36 \\
\hline
\end{tabular}

Only 11 of the accessions had an accelerated ageing germination percentage of above $50 \%$. The accelerated ageing germination values for the accessions varied from $0 \%$ to $91.33 \%$ (Table 4). Accessions ENAGmg 1 and ENNSog revealed a higher accelerated ageing germination percentage values than their standard germination percentage values, while other accessions had lesser values. Also, the accelerated ageing index values ranged from 3.88-6.17 days similar to the germination index values. All conductivity values for the 34 accessions were less than $5.00 \mu \mathrm{Scm}^{-1} \mathrm{~g}^{-1}$, except for ANISnn which had a value of $7.39 \mu \mathrm{Scm}^{-1} \mathrm{~g}^{-1}$. Conversely, accession ANISnn had the least vigour index value, while others had vigour index values ranging from 29.51 to 88.92 . The water imbibed percentage varied from $64.10 \%$ (ENAGag) to $88.98 \%$ (EBIKea), while the duration in which the water was imbibed varied from $42 \mathrm{hrs}$ to $66 \mathrm{hrs}$. Half of the accessions had VI above 65\% (88.92-65.11) and the other half below, ranging from 25.12-64.81. The first 7 accessions with the highest VI were from Enugu and Imo States (Table 4).

From the correlation result (Table 5), a highly significant $(\mathrm{p}<0.01)$ negative correlation existed between hundred seed weight and accelerated ageing water imbibed, hundred seed weight and percentage water imbibed, germination percentage and conductivity, conductivity and vigour index, and between percentage water imbibed and duration of imbibition. Whereas a highly significant $(\mathrm{p}<0.01)$ positive correlation existed between germination percentage and accelerated ageing germination percentage, germination percentage and vigour 
index, accelerated ageing germination percentage and vigour index. Also, a significant $(\mathrm{p}<0.05)$ positive correlation existed between hundred seed weight and the duration of imbibition, germination index and duration of imbibition, accelerated ageing index and duration of imbibition. Furthermore, relationship between accelerated ageing germination percentage and conductivity, and between accelerated ageing germination percentage and percentage water imbibed were significant $(\mathrm{p}<0.05)$ but negative.

Table 5. Correlation analysis of the seed physiological quality tests of the 34 African yam bean accessions $(\mathrm{n}=$ 32)

\begin{tabular}{llllllllll}
\hline & HSW & GPCT & GI & WIA & AAT & AAI & COND & VI & WIP \\
\hline GPCT & 0.21 & & & & & & & & \\
GI & -0.02 & -0.22 & & & & & & & \\
WIA & $-0.47^{* *}$ & -0.04 & -0.12 & & & & & & \\
AAT & $0.38^{*}$ & $0.63^{* *}$ & -0.09 & 0.03 & & & & & \\
AAI & 0.03 & 0.03 & 0.19 & -0.10 & -0.02 & & & & \\
COND & 0.02 & $-0.54^{* *}$ & -0.01 & -0.09 & $-0.41^{*}$ & -0.19 & & \\
VI & 0.31 & $0.91^{* *}$ & -0.18 & -0.004 & $0.88^{* *}$ & 0.01 & $-0.58^{* *}$ & & \\
WIP & $-0.69^{* *}$ & -0.14 & -0.07 & 0.30 & $-0.40^{*}$ & -0.08 & -0.11 & -0.28 & \\
DIM & $0.42^{*}$ & 0.10 & $0.40^{*}$ & -0.23 & 0.17 & $0.44^{*}$ & 0.06 & 0.14 & $-0.53^{* *}$ \\
\hline
\end{tabular}

Note. HSW: Hundred Seed weight (g); GPCT: Germination percentage (\%); GI: Germination index; WIA: Water imbibed during accelerated aging (\%); AAT: Accelerated ageing germination percentage (\%); AAI: Accelerated aging germination index; COND: Conductivity per gram of seed $\left(\mu \mathrm{Scm}^{-1} \mathrm{~g}^{-1}\right)$; VI: Vigour index; WIP: Percentage water imbibed (\%); DIM: Duration of imbibition (hrs).

\section{Discussion}

The accessions exhibited a widely divergent variability for both physical and physiological traits. The wide variability in the performance of the African yam bean accessions across the seed physical and physiological quality tests corroborates the report of Adewale and Odoh (2013) that Nigeria is among the centers of diversity of African yam bean. Olasoji, Akande, and Owolade, (2011) also reported genetic variability for seed quality among 10 accessions of AYB studied. The variation was observed in their seed sizes, amount and rate of water imbibed in the process of germination, viability status and speed of germination, ability to withstand stress or adverse conditions and the integrity of their seed coats. Accessions ENAGag, ENAGmg 1 and ENAGmg 2 had comparative larger seeds than other accessions and showed similarities in their performances across the tests indicating that they were of a similar genetic background. Seed size is an important physical indicator of seed quality that affects seed germination, emergence, seedling survival, plant growth and performance of the crop in the field (Adebisi et al., 2013; Makinde, Oyekale, \& Daramola, 2020). The outstanding performances of large-seeded accessions can be attributed to their higher reserve content. Shahi, Bargahi, and Bargali, (2015) reported that distinct seed sizes have different levels of starch and other energy reserves which may be an important factor to improve the expression of germination and initial growth of seedlings. The seed size of the accessions also varied across their location of collection. Although, it is believed that seed sizes may vary widely between the crop species and the germination and growth environment, generally, large seeds have a higher seedling survival rate, larger biomass and adaptability than small seeds, under adverse conditions (Ambika, Manonmani, \& Somasundaram, 2014).

The failure of accession ANISnn to germinate under stress and ideal conditions suggests that the embryo must have been dead despite that other features of the seed remain intact and dormancy is not associated with African yam bean (Olisa et al., 2010a). This loss of physiological quality could have been as a result of the inherent low vigour of African yam bean seeds upon which is superimposed a poor storage environment. Accessions EBANau and EBIKok were also losing their germination potential, revealing a gradual decline in viability and vigour owing to physiological deterioration. Physiological seed deterioration is a phenomenon which is not visually apparent. The inability of seeds to maintain vigour for a long period poses storage problems and can cause the specie/crop to go into extinction (Finch-Savage \& Bassel, 2016).

Most of the accessions had very low vigour as revealed by their low germination after being subjected to accelerated ageing. This corroborates the fact that African yam bean seeds are inherently low in seed vigour (Olisa et al., 2010a). The significant positive relationship between standard germination percentage and 
accelerated ageing germination percentage suggests that, accessions with higher germination under stress conditions will also exhibit higher germination under normal conditions, while poor germination under normal conditions will lead to poor performance under stress conditions. However, that some accessions like ENAGag, ENAGmg 1, ENAGmg 2, ENNKob, ENNSog, IMISis, IMOKeo 1 and IMOKeo 3 had higher and comparable standard germination and accelerated ageing germination percentages suggests that there exist a pool of high seed vigour potential among the African yam bean accessions that can be improved upon. High seed vigor enhances the ability to obtain optimal plant densities and high crop yields (Milosevic, Vujakovic, \& Karagic, 2010). The germination index and accelerated ageing index values indicated that African yam bean seed germination occurs between averages of 4-7 days, whether under ideal or stressed conditions. These two test procedures (standard germination and accelerated ageing tests) alongside conductivity test were the key determinants of the vigour index of the accessions. The consistently low conductivity values for all the accessions could be as a result of their hard seed coat which could in turn reduce seed exudates. Tungate, Susko, and Rufty (2002) attributed low germination rate to the prevention of water and respiratory gases from penetrating into the seed by hard seed coats during imbibition. However, the considerably low conductivity values also indicated that the seeds were suitable for sowing. According to Hampton and TeKrony (1995) conductivity values less than $30 \mu \mathrm{Scm}^{-1} \mathrm{~g}^{-1}$ indicate that the seeds are suitable for sowing, even under adverse conditions.

Even though the amount and duration of water imbibed did not follow any definite pattern nor correlate with the number of seeds that germinated, their persistent correlation with hundred seed weight under ideal conditions (WIP) and under stress (WIA) revealed that imbibition is strongly influenced by or dependent on the size or weight of the seed. Olisa et al. (2010b) stated that the duration of each phase of imbibition in African yam bean depended on seed properties such as size, content of hydratable substances, seed coat permeability and oxygen uptake. However, the speed of germination under both ideal and stress conditions in this study were influenced by the duration of water imbibed. That is, a delay in the number of days of the seed to germinate extended also the period during which water is imbibed prior to germination, without necessarily increasing the overall amount of water imbibed. On the average, African yam bean seeds require moisture of up to $76.9 \%$ of their initial weight over a period of approximately 53 hours prior for the commencement of germination.

\section{Conclusion}

Seed size is an important trait in African yam bean that could be improved upon for the selection of landraces of high seed physiological potentials. Conductivity test was not very effective in determining the variability in seed vigour. Seed germination in AYB can be easily assessed 7 days after planting. Accessions ENAGag, ENAGmg 1, ENAGmg 2, ENNKob, ENNSog, IMISis, IMOKeo 1 and IMOKeo 3 were outstanding and are therefore recommended for genetic improvement of seed quality in African yam bean.

\section{Acknowledgements}

This work was supported under the CIRCLE Visiting Fellowship programme funded by the UK Department for International Development (DfID). Neither the findings nor the views expressed, however, necessarily reflect the policies of the UK Government.

\section{References}

Adebisi, M. A., Kehinde, T. O., Salau, A. W., Okesola, L. A., Porbeni, J. B. O., Esuruoso, A. O., \& Oyekale, K. O. (2013). Influence of different seed size fractions on seed germination, seedling emergence and seed yield characters in tropical soybean (Glycine max L. Merrill). International Journal of Agricultural Research, 8(1), 26-33. https://doi.org/10.3923/ijar.2013.26.33

Adewale, B. D., \& Odoh, N. C. (2013). A review on genetic resources, diversity and agronomy of African Yam Bean (Sphenostylis stenocarpa (Hochst. Ex A. Rich.) Harms): A potential future food crop. Sustainable Agriculture Research, 2, 3-43. https://doi.org/10.5539/sar.v2n1p32

Ambika, S., Manonmani, V., \& Somasundaram, G. (2014). Review on effect of seed size on seedling vigour and seed yield. Research Journal of Seed Science, 7(2), 31-38. https://doi.org/10.3923/rjss.2014.31.38

Awosanmi, F. E. (2010). Effect of genotype and drought on seed vigour in maize (Zea mays L.) (p. 67, Thesis, Obafemi Awolowo University, Ile-Ife, Nigeria).

Binotti, F. F. S., Haga, K. I., Cardoso, E. D., Alves, C. Z., De Sá, M. E., \& Arf, O. (2008). Effect of the accelerated aging period on the electrical conductivity test and on the physiological quality of bean seeds. Acta Scientiarum Agronomy, 30(2), 247-254. https://doi.org/10.4025/actasciagron.v30i2.1736 
Eggert, K., \& von Wirén, N. (2015). The role of boron nutrition in seed vigour of oilseed rape (Brassica napus L.). Plant and Soil, 402, 63-76. https://doi.org/10.1007/s11104-015-2765-1

Egli, D. B., \& Rucker, M. (2012). Seed Vigor and the Uniformity of Emergence of Corn Seedlings. Crop Science, 52, 2774-2782. https://doi.org/10.2135/cropsci2012.01.0064

Fakorede, M. A. B., \& Agbana S. B. (1983). Heterotic effects and association of seedling vigour with mature plant characteristics and grain yield in some tropical maize cultivars. Maydica, 27, 327-338.

Finch-Savage, W. E. (1995). Influence of seed quality on crop establishment, growth and yield. In A. S. Basra (Ed.), Seed Quality: Basic Mechanisms and Agricultural Implications (pp. 361-384). Food Products Press: New York, NY, USA. https://doi.org/10.4324/9781003075226-11

Finch-Savage, W. E., \& Bassel, G. W. (2016). Seed vigour and crop establishment: Extending performance beyond adaptation. Journal of Experimental Botany, 67(3), 567-591. https://doi.org/10.1093/jxb/erv490

Hampton, J. G., \& TeKrony, D. M. (1995). Handbook of Seed vigour Test Methods. International Seed Testing Association, Zurich.

Hofs, J. L. Schoeman, A., \& Vaissayrel, M. (2004). Effect of Bt cotton on arthropod biodiversity in South African Cotton fields. Communications in Agricultural and Applied Biological Sciences, 69(3), 191-194.

ISTA (International Seed Testing Association). (2018). International Rules for Seed Testing. International Seed Testing Association, Zurich.

Kandasamy, S., Weerasuriya, N., Gritsiouk, D., Patterson, G., Saldias, S., Ali, S., \& Lazarovits, G. (2020). Size Variability in Seed Lot Impact Seed Nutritional Balance, Seedling Vigor, Microbial Composition and Plant Performance of Common Corn Hybrids. Agronomy, 10(2), 1-17. https://doi.org/10.3390/agronomy100 20157

Makinde, A. I., Oyekale, K. O., \& Daramola, D. S. (2020). Impact of seed size on the seedling vigour, dry matter yield and oil content of Jatropha (Jatropha curcas L.). Journal of Agricultural Science, 12(3), 197-203. https://doi.org/10.5539/jas.v12n3p197

Marcos-Filho, J. (2015). Seed vigor testing: An overview of the past, present and future perspective. Scientia Agricola, 72(4), 363-374. https://doi.org/10.1590/0103-9016-2015-0007

Medeiros A. D., Silva, L. J., Capobiango, N. P., Fialho, C. A., \& Dias, D. C. F. S. (2019). Assessing the physiological quality of common bean seeds using the Vigor-S ${ }^{\circledR}$ system and its relation to the accelerated aging test. Journal of Seed Science, 41(2), 187-195. https://doi.org/10.1590/2317-1545v41n2211401

Milosevic, M., Vujakovic, M., \& Karagic, D. (2010). Vigour tests as indicators of seed viability. Genetika, 42, 103-118. https://doi.org/10.2298/GENSR1001103M

Nnamani, C. V., Ajayi, S. A., Oselebe, H. O., Atkinson, C. J., Igboabuchi, A. N., \& Ezigbo, E. C. (2017). Sphenostylis stenocarpa (ex. A. Rich.) Harms. a Fading Genetic Resource in a Changing Climate: Prerequisite for Conservation and Sustainability. Plants, 6(30), 1-16. https://doi.org/10.3390/plants6030030

Olasoji, J. O., Akande, S. R., \& Owolade, O. F. (2011). Genetic variability in seed quality of African yam beans (Sphenostylis stenocarpa Hochst. Ex A. Rich Harms). African Journal of Agricultural Research, 6(27), 5848-5853. https://doi.org/10.5897/AJAR11.1311

Olisa, B. S., Ajayi, S. A., \& Akande, S. R. (2010a). Physiological Quality of Seeds of Promising African Yam Bean (Sphenostylis stenocarpa (Hochst. Ex A. Rich) Harms) and Pigeon Pea (Cajanus cajan L. Mill sp.) Landraces. Research Journal of Seed Science, 3, 93-101. https://doi.org/10.3923/rjss.2010.93.101

Olisa, B. S., Ajayi, S. A., \& Akande, S. R. (2010b). Imbibition and Response of Pigeon Pea (Cajanus cajan L. Mill sp.) and African Yam Bean (Sphenostylis stenocarpa (Hochst. ex A. Rich) Harms) Seeds to Scarification. Research Journal of Seed Science, 3, 150-159. https://doi.org/10.3923/rjss.2010.150.159

Potter, D. (1992). Economic Botany of Sphenostylis stenocarpa (Leguminosae). Economic Botany, 46, $262-275$. https://doi.org/10.1007/BF02866625

Potter, D., \& Doyle, J. J. (1992). Origin of African yam bean (Sphenostylis stenocarpa, Leguminosae): Evidence from morphology, isozymes, chloroplast DNA and Linguistics. Economic Botany, 46, $276-292$. https://doi.org/10.1007/BF02866626 
Shahi, C. V., Bargahi, K., \& Bargali, S. S. (2015). How seed size and water stress affect the seed germination and seedling growth in wheat varieties? Current Agriculture Research Journal, 3(1), 60-68. https://doi.org/ 10.12944/CARJ.3.1.08

Silva, C. B., Lopes, M. M., Marcos-Filho, J., \& Vieira, R. D. (2012). Automated system of seedling image analysis (SVIS) and electrical conductivity to assess sun hemp seed vigor. Revista Brasileira de Sementes, 34(1), 55-60. https://doi.org/10.1590/S0101-31222012000100007

Tungate, K. D., Susko, D. J., \& Rufty, T. W. (2002). Reproduction and offspring competitiveness of Senna obtusifolia are influenced by nutrient availability. New Phytologist, 154, 661-669. https://doi.org/10.1046/ j.1469-8137.2002.00407.x

Uguru, M. I., \& Madukaife, S. O. (2001). Studies on the variability in agronomic and nutritive characteristics of African yam bean (Sphenostylis stenocarpa Hochst ex. A. Rich. Harms). Plant Production and Research Journal, 6, 10-19.

Venuto, B. C., Redfearn, D. D., Pitman, W. D., \& Alison, M. W. (2002). Seed variation among annual ryegrass cultivars in south-eastern USA and the relationship with seedling vigour and forage production. Grass and Forage Science, 57, 305-311. https://doi.org/10.1046/j.1365-2494.2002.00328.x

\section{Copyrights}

Copyright for this article is retained by the author(s), with first publication rights granted to the journal.

This is an open-access article distributed under the terms and conditions of the Creative Commons Attribution license (http://creativecommons.org/licenses/by/4.0/). 